\title{
ANALYSING THE DRYING BEHAVIOR OF JUVENILE AND MATURE Eucalyptus saligna WOOD IN DRASTIC DRYING TEST FOR OPTIMAL DRYING SCHEDULE
}

\author{
Bruno Charles Dias Soares ${ }^{1, \star}$, José Tarcísio Lima², \\ José Reinaldo Moreira da Silva ${ }^{2}$
}

\begin{abstract}
The heterogeneity of characteristics observed in the pith-bark direction within a log causes sawn pieces of wood have different behaviors during water removal. Understanding these differences is important for the industry regarding the possibility of classification of the lumber into juvenile wood and mature wood, facilitating the drying in separate loads. Thus, this study aimed to evaluate the behavior of juvenile and mature wood samples of Eucalyptus saligna when subjected to drastic drying. In order to do this, test specimens were submitted to drastic drying at $100^{\circ} \mathrm{C}$ to obtain the drying times, drying rates and dimensions of end checks. These data were applied in equations to obtain the parameters initial temperature, final temperature and drying potential, used in the elaboration of drying schedules. In juvenile wood we observed that the basic density was lower and the initial moisture content was higher. Mature wood showed a lower drying rate. Drying schedules were developed separately for juvenile and mature wood, the drying schedule for the latter considered milder than the drying schedule developed for juvenile wood.
\end{abstract}

Keywords: Drying potential, drying rate, drying time, end checks, moisture content.

\section{INTRODUCTION}

The removal of water during drying causes stress in the internal and external layers of the lumber which may cause defects like warping, checking and casehardening. The effect of this process in wood is important, since it is desirable that the dry wood is free of defects. The appearance of drying stress, to a greater or lesser degree, is a function of the intrinsic characteristics of permeability, anatomical structure, density and mechanical strength of wood, together with the drying conditions under which the lumber is subjected.

For better control of drying condition, the lumber is subjected to kiln drying which aims to promote a balance between the water evaporation rate on the wood surface, the internal movement rate (both heat and moisture) and reactions from wood during the process, so as to dry the wood as fast as possible with an acceptable loss level and quality standard (Jankowsky 1995). For this, the lumber is subjected to drying following schedules developed according to its characteristics. The humidity-temperature type schedules are the most common, in which the temperature and relative humidity inside the kiln are adjusted according to the wood moisture content (Hildebrand 1970, Pratt 1974).

\footnotetext{
${ }^{1}$ Forest Engineer, Ph.D. student in Wood Science and Technology - Departamento de Ciências Florestais - Universidade Federal de Lavras, Lavras, Brazil.

${ }^{2}$ Forest Engineer, Professor, Ph.D. - Departamento de Ciências Florestais - Universidade Federal de Lavras, Lavras, Brazil. jtlima@dcf.ufla.br; jreinaldo@dcf.ufla.br

${ }^{\otimes}$ Corresponding author: bruno.soares_18@hotmail.com

Received: 23.06.2015 Accepted: 06.06.2016
} 
Brandão (1989), based on Terazawa (1965), tested the viability of using a methodology which related the occurrences of different grades of check and collapse resulting from drying at $100^{\circ} \mathrm{C}$ of small wood samples $(2,50 \mathrm{~cm} \times 5 \mathrm{~cm} \times 10 \mathrm{~cm})$ with the initial temperature, final temperature and drying potential in schedules found in the literature for different types of wood. The author concluded that the methodology used was efficient to predict the behavior of a specific lumber, when submitted to conventional drying. It was also concluded that the drying rate and the end check were the most important variables for the elaboration of drying schedules. Jankowsky et al. (1997) developed work that allowed to improve the methodology discussed by Brandão (1989), setting the drying time, the drying rate and the end checks as the characteristics that most influence the elaboration of drying schedules and the development of equations to estimate the drying initial temperature, drying final temperature and drying potential. This methodology was used by several authors in Brazil (Ciniglio 1998, Andrade 2000, Santos 2002, Barbosa et al. 2005, Batista 2009, Susin 2012), allowing the development of drying schedules which, when tested, showed efficiency for use in conventional drying. Despite the difference of age among the lumber analyzed by those authors, the drying parameters found showed similar values.

It is known that a lumber drying load should be constituted of pieces only of the same species and only with one dimension (Hildebrand 1970, Pratt 1974). However, it is also known that there are variations in the wood properties within the log, which in many cases exceed the average variation among species. Among these variations special attention should be given to the differences between the properties of juvenile wood and mature wood.

The juvenile wood consists of a central stem region with lower density, the fibers having a less wall thickness and shorter length (Silva 2002, Cobas et al. 2013) and greater microfibril angle in the $\mathrm{S}_{2}$ layer of the fiber cell walls (Lima et al. 2014). The mature wood presents contrasting dimensions of these traits with juvenile wood, allowing the establishing of a transition point between the two types of woods when observing the behavior of these traits in the pith-bark direction.

The anatomical differences between juvenile wood and mature wood may reflect different behaviors when subjected to drying, and understanding the difference between these wood variations can be important for the industry as to drying optimization, since once these differences are known, one can choose to perform the sawing of logs aimed at board classification, enabling drying in separate loads of lumber from juvenile and mature wood. Besides the importance of the knowledge about these differences and the possibility to apply it to improve wood processing and use, a little information about Eucalyptus wood has been published.

Thus, the purpose of this study was to evaluate the behavior of juvenile and mature Eucalyptus saligna wood samples when subjected to drastic drying. As a secondary aim, drying schedules was developed for both juvenile and mature wood using moisture loss and the occurrence of defects after drastic drying as a basis.

\section{MATERIAL AND METHODS}

Two randomly selected Eucalyptus saligna trees were felled at the age of 37 years. They were selected an experimental plantation of the Federal University of Lavras farm, located in Lavras - MG, Brazil, $21^{\circ} 14^{\prime} 4$ " S and $44^{\circ} 59^{\prime} 5^{\prime \prime} \mathrm{W}$.

The heights and diameters at breast height $(\mathrm{DBH})$ of the trees were measured; Tree 1 measuring 42 meters tall with $58 \mathrm{~cm}$ of DBH, and Tree 2 measuring 43 meters tall with $61 \mathrm{~cm}$ of DBH.

After felling the trees, the trunks were divided into three-meter logs, and the basal logs were used for manufacture of the drying test samples. 
The sawing of the logs was made by the tangential alternate parallel to the center of the log method in a band saw. The nominal dimensions of the sawn pieces were $300 \mathrm{~cm} \times 20 \mathrm{~cm} \times 2,5 \mathrm{~cm}$ (length, width and thickness). These boards were sawn again to reach the dimensions of $100 \mathrm{~cm} \times 20 \mathrm{~cm} \times$ $2,5 \mathrm{~cm}$ and after this were planed to reach the final thickness of $1 \mathrm{~cm}$. For this study, six boards from each $\log (100 \mathrm{~cm} \times 20 \mathrm{~cm} \times 1 \mathrm{~cm})$ were used, being three boards representing the juvenile wood and three representing the mature wood. All the sample processing was carried out with minimum interval between the steps in order to reduce moisture loss. After that, the samples were kept within a container of water to maintain moisture content prior to conducting the drastic drying test.

The boards were separated into juvenile wood boards and mature wood boards, considering the determination made in a preliminary test with the same trees, by analyzing the radial variation of fibers length, which increases in the pith-bark direction and stabilizes in an intermediary position between this two points, characterizing the transition between juvenile wood and mature wood. According to this test, the transition between the juvenile and mature wood of E. saligna occurs between the 8th and the 9th growth ring, which can serve as practical definition for log sawing and subsequent separation of the boards to dry.

For the development of the drying schedules, we used the methodology of drastic drying used by Ciniglio (1998), which involves submitting $100 \mathrm{~mm} \times 50 \mathrm{~mm} \times 10 \mathrm{~mm}$ samples of green lumber to $100^{\circ} \mathrm{C}$ in a laboratory drying oven and recording the drying time and manifestation of defects as the samples reach predetermined moisture content of $30 \%$ and $5 \%$.

Eighteen samples were made from the $100 \mathrm{~cm} \times 20 \mathrm{~cm} \times 1 \mathrm{~cm}$ boards, representing the juvenile wood and mature wood portions for each log, for the elaboration of each drying schedule. Of these, six samples were separated for determining the initial moisture content (A), six samples for the determination of the density (B) and six samples for testing in the kiln (C), as shown in Figure 1.

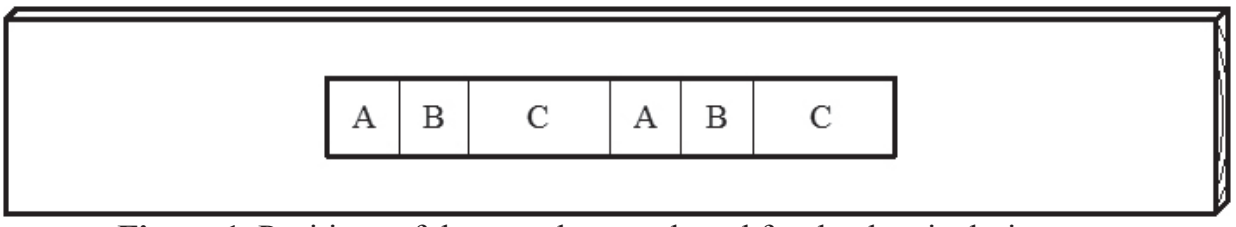

Figure 1. Positions of the samples on a board for the drastic drying test.

A - Sample for determination of initial moisture content $(50 \times 50 \times 10 \mathrm{~mm})$

B - Sample for determination of basic density $(50 \times 50 \times 10 \mathrm{~mm})$

$\mathrm{C}$ - Sample for drying at $100^{\circ} \mathrm{C}(100 \times 50 \times 10 \mathrm{~mm})$

The initial and final moisture contents of the samples were determined employing the gravimetric method, and the basic density was obtained according to the NBR 11941-02 (ABNT 2003).

For the development of the drying schedules, the samples were submitted to drying in a laboratory drying oven, with a forced air circulation system. During the drastic drying, the mass loss and the evolution of the end checks were measured periodically (every 30 minutes between the initial moisture content and 30\% moisture content; every 60 minutes between $30 \%$ moisture content and $15 \%$ moisture content; every 120 minutes between $15 \%$ moisture content and 5\% moisture content) via the check width measurement with the aid of a feeler gauge and the check length with a caliper, always considering the highest occurrence intensity. At the same intervals, the mass loss was determined until the samples reach $5 \%$ moisture content.

The end check values were converted into scores according to the criteria presented in Table 1. The water loss values were used to calculate the drying rate. Based on those values the variables of the drastic drying test, necessary for the calculation of the drying schedule parameters, were calculated (Table 2). 
Table 1. Score attributed to the magnitudes of the end checks presented in the samples submitted to drastic drying oven.

\begin{tabular}{|c|c|}
\hline Score & End check \\
\hline 1 & Absent \\
\hline 2 & $\mathrm{CL}<5,0$ and $\mathrm{CW}<0,5$ \\
\hline 3 & $\mathrm{CL}>5,0$ and $\mathrm{CW}<0,5$ \\
\hline 4 & $\mathrm{CL}<5,0$ and $0,5<\mathrm{CW}<1,0$ \\
\hline 5 & $\mathrm{CL}>5,0$ and $0,5<\mathrm{CW}<1,0$ \\
\hline 6 & $\mathrm{CL}>5,0$ and $\mathrm{CW}>1,0$ \\
\hline
\end{tabular}

Table 2. Variables of the drastic drying test.

\begin{tabular}{|c|c|c|c|}
\hline Variable & Description & Moisture content range & Unit \\
\hline IMC & Initial moisture content & Green & $\%$ \\
\hline T1 & Drying time & IMC to $5 \%$ & $\mathrm{~h}$ \\
\hline T2 & Drying time & IMC to $30 \%$ & $\mathrm{~h}$ \\
\hline T3 & Drying time & $30 \%$ to $5 \%$ & $\mathrm{~h}$ \\
\hline R1 & Drying rate & IMC to $5 \%$ & $\mathrm{~g} \cdot \mathrm{cm}^{-2} \cdot \mathrm{h}^{-1}$ \\
\hline R2 & Drying rate & IMC to $30 \%$ & $\mathrm{~g} . \mathrm{cm}^{-2} \cdot \mathrm{h}^{-1}$ \\
\hline R3 & Drying rate & $30 \%$ to $5 \%$ & $\mathrm{~g} \cdot \mathrm{cm}^{-2} \cdot \mathrm{h}^{-1}$ \\
\hline C1 & End check & IMC to $5 \%$ & $\mathrm{score}$ \\
\hline C2 & End check & IMC to $30 \%$ & score \\
\hline C3 & End check & $30 \%$ to $5 \%$ & score \\
\hline
\end{tabular}

The calculation of the drying rate was according to Equations 1,2 and 3.

a) Drying rate between initial moisture content and 5\%: $R_{1}=\frac{m_{i}-m_{5}}{T_{1} \times 100}$

Where in:

$\mathrm{R}_{1}=$ drying rate between initial moisture content and 5\% $\left(\mathrm{g} \cdot \mathrm{cm}^{-2} \cdot \mathrm{h}^{-1}\right)$;

$\mathrm{m}_{\mathrm{i}}=$ mass of the sample at the initial moisture content $(\mathrm{g})$;

$\mathrm{m}_{5}=$ mass of the sample at the $5 \%$ moisture content $(\mathrm{g})$;

$\mathrm{T}_{1}=$ drying time between initial moisture content and 5\% (h);

$100=$ surface area of the sample $\left(\mathrm{cm}^{2}\right)$.

b) Drying rate between initial moisture content and 30\%: $R_{2}=\frac{m_{i}-m_{30}}{T_{2} \times 100}$

Where in:

$\mathrm{R}_{2}=$ drying rate between initial moisture content and $30 \%\left(\mathrm{~g} \cdot \mathrm{cm}^{-2} \cdot \mathrm{h}^{-1}\right)$;

$\mathrm{m}_{\mathrm{i}}=$ mass of the sample at the initial moisture content $(\mathrm{g})$;

$\mathrm{m}_{30}=$ mass of the sample at the $30 \%$ moisture content $(\mathrm{g})$;

$\mathrm{T}_{2}=$ drying time between initial moisture content and 30\% (h); 
$100=$ surface area of the sample $\left(\mathrm{cm}^{2}\right)$.

c) Drying rate between $30 \%$ and $5 \%$ moisture content: $R_{3}=\frac{m_{30}-m_{5}}{T_{3} \times 100}$

Where in:

$\mathrm{R}_{3}=$ drying rate between $30 \%$ and $5 \%$ moisture content $\left(\mathrm{g} \cdot \mathrm{cm}^{-2} \cdot \mathrm{h}^{-1}\right)$;

$\mathrm{m}_{30}=$ mass of the sample at the $30 \%$ moisture content (g);

$\mathrm{m}_{5}=$ mass of the sample at the $5 \%$ moisture content $(\mathrm{g})$;

$\mathrm{T}_{3}=$ drying time between $30 \%$ and $5 \%$ moisture content $(\mathrm{h})$;

$100=$ surface area of the sample $\left(\mathrm{cm}^{2}\right)$.

The determination of the parameters for the drying schedules was made by Equations 4, 5 and 6, according to the drastic drying methodology, demonstrated by Ciniglio (1998).

$$
\begin{aligned}
& \mathrm{IT}=27,9049+0,7881 \times \mathrm{T}_{2}+419,0254 \times \mathrm{R}_{1}+1,9483 \times \mathrm{C}_{1} \\
& \mathrm{FT}=49,2292+1,1834 \times \mathrm{T}_{2}+273,8685 \times \mathrm{R}_{2}+1,0754 \times \mathrm{C}_{1} \\
& \mathrm{DP}=1,4586-30,4418 \times \mathrm{R}_{3}+42,9653 \times \mathrm{R}_{1}+0,1424 \times \mathrm{C}_{3}
\end{aligned}
$$

Where in: IT $=$ Initial temperature $\left({ }^{\circ} \mathrm{C}\right) ; \mathrm{FT}=$ Final temperature $\left({ }^{\circ} \mathrm{C}\right) ; \mathrm{DP}=$ Drying potential.

The drying schedules were developed with the aid of psychrometric charts, so that the initial temperature (IT) defined by Equation 4 was fixed to the stage of initial moisture content until it reaches $40 \%$ moisture content. A five percent variation was adopted in the schedule steps in order to promote small and gradual increases in drying temperature. These steps, along the moisture content range for each step, were established and used identically for the two drying schedules.

The completely randomized design was used for statistical analysis, according to the model $Y_{i j}=$ $\mu+t_{i}+e_{i j}$, wherein:

$Y_{i j}=$ value of the variable tested under the i-th level of treatment;

$\mu=$ overall average for the variable;

$t_{i}=$ effect of the $\mathrm{i}$-th level of treatment;

$e_{i j}=$ random error.

The average values were obtained from twelve observations made in both juvenile and mature wood of the trees investigated, according to the sampling previously described. The analysis of variance (ANOVA) was performed at 5\% significance to compare the average values found in the juvenile wood and in the mature wood for: initial moisture content, basic density, drying time, drying rate, initial temperature, final temperature and drying potential. 


\section{RESULTS AND DISCUSSION}

Table 3 shows the average values of initial moisture content and basic density of the samples for drying assay at $100^{\circ} \mathrm{C}$.

Table 3. Average values of initial moisture content and basic density of samples of juvenile and mature wood of Eucalyptus saligna subjected to drastic drying.

\begin{tabular}{|c|c|c|}
\hline Wood & Basic density $\left(\mathrm{kg} . \mathrm{m}^{-3}\right)$ & Initial moisture content (\%) \\
\hline Juvenile & 636 & 84,21 \\
\hline Mature & 735 & 62,62 \\
\hline F calculated & $26,16^{*}$ & $25,45^{*}$ \\
\hline$*=$ significant to $\%$. &
\end{tabular}

Table 3 indicates that the average basic density in different types of Eucalyptus saligna wood differs statistically, being $15,6 \%$ higher in the mature wood than in juvenile wood.

The average basic density found in E. saligna wood was $686 \mathrm{~kg} \cdot \mathrm{m}^{-3}$, close to the $690 \mathrm{Kg} \cdot \mathrm{m}^{-3}$ found by Susin (2012) for the same species with at 40 years of age. Lopes and Garcia (2002) found average basic density of $620 \mathrm{~kg} \cdot \mathrm{m}^{-3}$ for this species at 22 years of age, being lower than that presented in Table 3.

The initial moisture content of the samples was inversely proportional to the basic density (Table 3 ). This result is in accordance to Zanuncio et al. (2015), which found strong inverse correlation between moisture content and the basic density of Corymbia citriodora and Eucalyptus urophylla wood. This is comprehensive due to the capacity of the wood to retain water being related to its volume of voids. The calculation of the density considers the intra and intercellular spaces contained in the wood structure, whereas, the smaller the proportion of these spaces, the lower the water holding capacity and the greater the basic density.

The behavior of the average moisture content of the samples in relation to the drying time for juvenile and mature woods during drastic drying is shown in Figure 2.

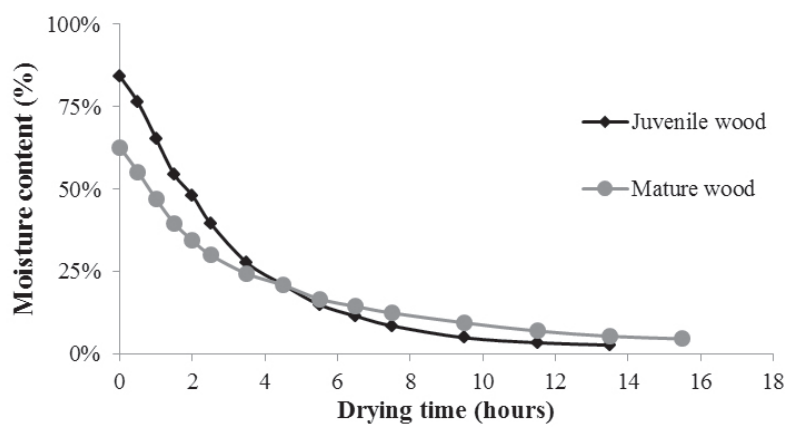

Figure 2. Drying curve with average moisture content and drying time values for samples of 37-yearold Eucalyptus saligna wood.

In Figure 2 we observed that the behavior of the drying curves presented by JW and MW differed since the beginning of drying until the fourth hour after the start of the drying test. This is possibly related to lower basic density and higher initial moisture content of juvenile wood. 
Samples of juvenile wood reached final moisture content of 5\% more quickly (Figure 2). This can be explained by higher total drying rate and higher drying rate of absorbed water found for JW in relation to MW (Table 4).

Table 4 lists the averages for the variables used to determine the drying schedule parameters.

Table 4. Average values for the variables of the drastic drying test in juvenile wood and mature wood of Eucalyptus saligna.

\begin{tabular}{|c|c|c|c|c|c|c|c|c|c|}
\hline Wood & $\mathrm{T}_{1}$ & $\mathrm{~T}_{2}$ & $\mathrm{~T}_{3}$ & $\mathrm{R}_{1}$ & $\mathrm{R}_{2}$ & $\mathrm{R}_{3}$ & $\mathrm{C}_{1}$ & $\mathrm{C}_{2}$ & $\mathrm{C}_{3}$ \\
\hline Juvenile & 9,50 & 3,00 & 6,50 & 0,0270 & 0,0538 & 0,0144 & 2,17 & 2,17 & 1,33 \\
\hline Mature & 13,50 & 2,25 & 11,25 & 0,0161 & 0,0518 & 0,0089 & 1,50 & 1,33 & 1,50 \\
\hline F calculated & $44,0^{*}$ & $19,8^{*}$ & $107,3^{*}$ & $40,6^{*}$ & $0,42^{\text {ns }}$ & $29,0^{*}$ & - & - & - \\
\hline
\end{tabular}

$\mathrm{T}_{1}=$ drying time between initial moisture content and $5 \%(\mathrm{~h}) ; \mathrm{T}_{2}=$ drying time between initial moisture content and $30 \%(\mathrm{~h}) ; \mathrm{T}_{3}$ $=$ drying time between $30 \%$ and $5 \%$ moisture content $(\mathrm{h}) ; \mathrm{R}_{1}=$ drying rate between initial moisture content and $5 \%\left(\mathrm{~g} \cdot \mathrm{cm}^{-2} \cdot \mathrm{h}^{-1}\right)$; $\mathrm{R}_{2}=$ drying rate between initial moisture content and $30 \%\left(\mathrm{~g} \cdot \mathrm{cm}^{-2} \cdot \mathrm{h}^{-1}\right) ; \mathrm{R}_{3}=$ drying rate between $30 \%$ and $5 \%$ moisture content $\left(\mathrm{g} . \mathrm{cm}^{-2} \cdot \mathrm{h}^{-1}\right) ; \mathrm{C}_{1}=$ end check between initial moisture content and $5 \%$ (score); $\mathrm{C}_{2}=$ end check between initial moisture content and $30 \%$ (score); $\mathrm{C}_{3}=$ end check between $30 \%$ and $5 \%$ moisture content (score); ns = not significant to $5 \% ; *=$ significant to $5 \%$.

As seen in Table 4, the drying time between initial moisture content and 5\% ( $\left.\mathrm{T}_{1}\right)$ was $30 \%$ lower in the juvenile wood. The mature wood, which presents the highest basic density, required higher total drying time and presented a lower total drying rate, which is in accordance with Siau (1971), who reported that, in general, the permeability of wood is inversely proportional to the density. These results indicate that the movement of water, from green to $5 \%$ moisture content, in juvenile wood is $40 \%$ quicker than in mature wood.

The drying time between initial moisture content and 30\% $\left(\mathrm{T}_{2}\right)$ refers to the time required for the free water to move out of the wood. The $T_{2}$ was statistically different between juvenile wood and mature wood (Table 4). This can be associated with the difference in the initial moisture content observed (Table 3), which was $25,64 \%$ higher in juvenile wood compared to mature wood, indicating that for being moister this wood needs higher time to reach the fiber saturation point. The similarity of the drying rates of initial moisture content to $30 \%$ found for juvenile wood and mature wood indicates similarity in free water movement in these woods.

The drying time between $30 \%$ and $5 \%$ moisture content indicates the time required for the adsorbed water to move out from the wood, being $42,2 \%$ greater for mature wood compared with juvenile wood. The $\mathrm{T}_{3}$ was responsible for most of the total drying time, representing $68 \%$ and $83 \%$ for JW and MW, respectively.

With respect to the end checks observed in the drastic drying test, the analysis of variance was not applied for comparison due to the high coefficient of variation of this variable. Nevertheless, the highest total score of checks was observed in juvenile wood (Table 4), but, the average score of the end checks, occurring between the $30 \%$ and $5 \%$ moisture content $\left(\mathrm{C}_{3}\right)$, was higher in the mature wood. The highest incidence of checks was observed between the initial moisture content and $30 \%\left(\mathrm{C}_{2}\right)$ for juvenile wood. This behavior above the saturation point of fibers is understandable, whereas the checks occur at the beginning of drying when the outer layers of the board, which dry first, are tensioned enough to break the link between the anatomical components of wood (Simpson 1991). In mature wood, the highest incidence of checks was observed in the drying between $30 \%$ and $5 \%$, with respect to the variable $\mathrm{C}_{3}$. Possibly, this occurred due to the low initial moisture content of this wood, so that a smaller percentage of the total drying time was needed for this wood to reach $30 \%$ moisture content compared to the juvenile wood. 
Table 5 presents the values found for initial temperature, final temperature and drying potential for juvenile wood and mature wood.

Table 5. Parameters of the drying schedules obtained from the drastic drying test for juvenile wood and mature wood of Eucalyptus saligna.

\begin{tabular}{|l|c|c|c|}
\hline Wood & $\mathrm{IT}\left({ }^{\circ} \mathrm{C}\right)$ & $\mathrm{FT}\left({ }^{\circ} \mathrm{C}\right)$ & DP $(\mathrm{Un})$. \\
\hline Juvenile & 45,81 & 69,86 & 2,37 \\
\hline Mature & 39,34 & 67,70 & 2,09 \\
\hline F calculated & $22,02^{*}$ & $3,91^{\text {ns }}$ & $19,32^{*}$ \\
\hline
\end{tabular}

$\mathrm{IT}=$ initial temperature; FT $=$ final temperature; $\mathrm{DP}=$ drying potential; $\mathrm{ns}=$ no significant to $5 \%$; $*$ = significant to $5 \%$.

The IT parameters shown in Table 5 for mature wood was $39,34^{\circ} \mathrm{C}$; close to that found by Batista (2009) and Susin (2012) for the same species at 11 and 40 years old, respectively. However, the IT value for juvenile wood was $45,81^{\circ} \mathrm{C}$; which is higher than the parameter found by those authors. In Table 5 it can be seen that the IT parameter of drying schedules was greater in juvenile wood. This indicates that boards of juvenile wood will tolerate higher temperatures at the beginning of drying compared to boards of mature wood when submitted to conventional drying.

The final temperatures (FT) presented in Table 5 for juvenile and mature wood are close to those found by Batista (2009) and Susin (2012) for E. saligna with 11 and 40 years of age, respectively (Table 6 ). In the analysis of variance performed for the FT parameter no difference was verified between the averages for JW and MW. However, it was observed that there was similarity between the FT parameters (Table 5) and those found in studies by Barbosa et al. (2005) and Susin (2012), shown in Table 6.

Regarding the drying potential (DP), Table 5 shows that there was no statistical difference between the averages for juvenile and mature E. saligna wood. The DP of juvenile wood was $13,4 \%$ higher than that found for mature wood. This can be explained by how this parameter is calculated (Equation 6), which takes into consideration the score of checks occurred in the range from $30 \%$ to $5 \%$ moisture content $\left(\mathrm{C}_{3}\right)$, which was $12,8 \%$ higher in the mature wood than the juvenile wood of this species.

The parameters obtained were coherent with those found in the literature (Table 6).

Table 6: Parameters of the drying schedules available in the literature for Eucalyptus wood.

\begin{tabular}{|l|l|l|l|l|}
\hline Species & IT $\left({ }^{\circ} \mathrm{C}\right)$ & FT $\left({ }^{\circ} \mathrm{C}\right)$ & DP $($ Un. $)$ & Author \\
\hline E. grandis & 40,5 & 64,9 & 2,10 & Ciniglio (1998) \\
\hline E. urophylla & 40,3 & 65,5 & 2,44 & Ciniglio (1998) \\
\hline E. grandis & 41,7 & 65,7 & 2,17 & Andrade (2000) \\
\hline E. tereticornis & 39,0 & 62,7 & 2,01 & Andrade (2000) \\
\hline E. grandis & 40,0 & 65,0 & 2,00 & Santos (2002) \\
\hline Eucalyptus spp & 43,9 & 66,8 & 2,20 & Barbosa et al. $(2005)$ \\
\hline E. saligna/grandis/dunnii & 40,0 & 66,0 & 2,00 & Batista (2009) \\
\hline E. saligna & 39,7 & 67,2 & 2,07 & Susin (2012) \\
\hline E. robusta & 37,2 & 67,0 & 1,92 & Susin $(2012)$ \\
\hline Corymbia citriodora & 38,8 & 68,5 & 2,08 & Susin $(2012)$ \\
\hline \multicolumn{1}{|l|}{ IT $=$ initial temperature; FT $=$ final temperature; DP $=$ Drying potential. } & \\
\hline
\end{tabular}

IT = initial temperature; FT = final temperature; $\mathrm{DP}=$ Drying potential. 
Table 6 presents low coefficients of variation for initial temperature $(3,15 \%)$; final temperature $(2,61 \%)$ and drying potential (7,20\%). This shows that for several species of Eucalyptus, drying schedules are generally mild. The drying schedules developed by these authors were tested by themselves and showed efficiency for use in conventional drying.

The drying schedules designed for juvenile wood and mature wood of Eucalyptus saligna can be seen in Tables 7 and 8 .

Table 7. Drying schedule for juvenile wood of Eucalyptus saligna.

\begin{tabular}{|l|c|c|c|c|c|}
\hline Drying step & DBT $\left({ }^{\circ} \mathrm{C}\right)$ & WBT $\left({ }^{\circ} \mathrm{C}\right)$ & RH $(\%)$ & EM $(\%)$ & DP (Un.) \\
\hline Heating & 46 & 45 & 97 & 23 & - \\
\hline Above $40 \%$ & 46 & 43 & 83 & 17 & 2,4 \\
\hline 40 to $35 \%$ & 50 & 46 & 80 & 14 & 2,4 \\
\hline 35 to $30 \%$ & 54 & 48 & 74 & 12 & 2,4 \\
\hline $30 \%$ to $25 \%$ & 58 & 50 & 65 & 10 & 2,4 \\
\hline $25 \%$ to $20 \%$ & 62 & 51 & 56 & 8 & 2,4 \\
\hline $20 \%$ to $15 \%$ & 66 & 50 & 43 & 6 & 2,4 \\
\hline $15 \%$ to $10 \%$ & 70 & 46 & 27 & 4 & 2,4 \\
\hline Equalizing & 70 & 63 & 70 & 10 & - \\
\hline Conditioning & 70 & 65 & 79 & 12 & - \\
\hline
\end{tabular}

$\mathrm{DBT}=$ dry bulb temperature, $\mathrm{WBT}=$ Wet bulb temperature, $\mathrm{RH}=$ relative humidity, $\mathrm{EM}=$ equilibrium moisture, $\mathrm{DP}=$ drying potential.

Table 8. Drying schedule for mature wood of Eucalyptus saligna.

\begin{tabular}{|l|c|c|c|c|c|}
\hline Drying step & DBT $\left({ }^{\circ} \mathrm{C}\right)$ & WBT $\left({ }^{\circ} \mathrm{C}\right)$ & RH $(\%)$ & EM (\%) & DP (Un.) \\
\hline Heating & 39 & 38 & 97 & 23 & - \\
\hline Above $40 \%$ & 39 & 37 & 91 & 20 & 2,0 \\
\hline 40 to $35 \%$ & 44 & 41 & 83 & 17 & 2,0 \\
\hline 35 to $30 \%$ & 49 & 45 & 82 & 15 & 2,0 \\
\hline $30 \%$ to $25 \%$ & 54 & 48 & 72 & 12 & 2,0 \\
\hline $25 \%$ to $20 \%$ & 59 & 51 & 66 & 10 & 2,0 \\
\hline $20 \%$ to $15 \%$ & 64 & 51 & 51 & 7 & 2,0 \\
\hline $15 \%$ to $10 \%$ & 68 & 48 & 34 & 5 & 2,0 \\
\hline Equalizing & 68 & 60 & 68 & 10 & - \\
\hline Conditioning & 68 & 63 & 76 & 12 & - \\
\hline
\end{tabular}

$\mathrm{DBT}=$ dry bulb temperature, $\mathrm{WBT}=$ Wet bulb temperature, $\mathrm{RH}=$ relative humidity, $\mathrm{EM}=$ equilibrium moisture, $\mathrm{DP}=\mathrm{drying}$ potential. 
In the drying schedules found in literature, some authors vary the drying potential when the drying stage changes. In Tables 7 and 8 the drying potentials obtained by the drastic drying test were sustained in all stages of the drying schedules, assuming that the wood will present satisfactory behavior when subjected to these schedules.

Table 8 shows that, due to the lower initial temperature and lower drying potential found for mature wood, the drying schedule for this wood was milder in relation to that developed for the juvenile wood. This may be related to a possible higher permeability of juvenile wood, which presented the highest drying rate, in general, in relation to mature wood when the samples were subjected to the same conditions in the kiln.

As a possible subsequent step, boards should be subject to such drying schedules in order to certify its effectiveness for juvenile and mature wood of E. saligna.

\section{CONCLUSIONS}

The methodology of the drastic drying applied on juvenile and mature wood of E. saligna allows to conclude that:

The juvenile wood behaves differently of mature wood with regard to the drying time, drying rate and the occurrence of end checks.

The initial temperature and drying potential were statistically lower on the mature than the juvenile wood. Consequently, a milder drying schedule is recommended for the mature wood drying.

\section{REFERENCES}

Andrade, A. 2000. Indicação de programas de secagem convencional de madeiras. M.S. Thesis, Escola Superior de Agricultura Luiz de Queiroz, Universidade de São Paulo, Piracicaba, Brasil.

Associação Brasileira de Normas Técnicas. 2003. NBR 11941-02: determinação da densidade básica em madeira. Rio de Janeiro, Brasil.

Barbosa, C.G.; Lima, J.T.; Rosado, S.C.S.; Trugilho, P.F. 2005. Elaboração de programa de secagem para madeiras de clones de híbridos de Eucalyptus spp. Cerne 11 (1): 40-48. 
Batista, D.C. 2009. Qualidade da secagem convencional conjunta da madeira de nove clones do gênero Eucalyptus. M.S. Thesis, Universidade Federal do Paraná, Curitiba, Brasil.

Brandão, A.T. de O. 1989. Determinação de metodologia para a indicação de programas de secagem de madeiras. M.S. Thesis, Escola Superior de Agricultura Luiz de Queiroz, Universidade de São Paulo, Piracicaba, Brasil.

Ciniglio, G. 1998. Avaliação da secagem de madeira serrada de E. grandis e E. urophylla. M.S. Thesis, Escola Superior de Agricultura Luiz de Queiroz, Universidade de São Paulo, Piracicaba, Brasil.

Cobas, A.C.; Area, M.C.; Monteoliva, S. 2013. Transición de madera juvenil a madura en un clon de Populus deltoides implantado en Buenos Aires Argentina. Maderas. Ciencia y Tecnología 15 (2): 223-234.

Hildebrand, R. 1970. Kiln drying of sawn timber. Maschinenbau GmbH, Berlin.

Jankowsky, I. P. 1995. Equipamentos e processos para secagem de madeiras. In. Seminário internacional de utilização da madeira de eucalipto para serraria. IPEF: 109-118.

Jankowsky, I.P.; Bilia, F.A.C.; Ducatti, M.A. 1997. Ensaio rápido para a seleção de programas de secagem. Relatório técnico CNPq 510555/93-4.

Lopes, G.A.; Garcia, J.N. 2002. Densidade básica e umidade natural da madeira de Eucalyptus saligna Smith, de Itatinga, associadas aos padrões de casca apresentados pela população. Scientia Forestalis 30 (62): 13-23.

Lima, J.T.; Ribeiro, A. de O.; Narciso, C. R. P. 2014. Microfibril angle of Eucalyptus grandis wood in relation to the cambial age. Maderas. Ciencia y Tecnología 16 (4): 487-494.

Pratt, G.H. 1974. Timber drying manual. Department of the Environment, London.

Santos, G.R.V. 2002. Otimização da secagem da madeira de Eucalyptus grandis (Hill ex Maiden). M.S. Thesis, Escola Superior de Agricultura Luiz de Queiroz, Universidade de São Paulo, Piracicaba, Brasil.

Siau, J.F. 1971. Flow in wood. Syracuse University, Syracuse.

Silva, J.R.M. da. 2002. Relações da usinabilidade e aderência do verniz com as propriedades fundamentais do Eucalyptus grandis hill ex. Maiden. Ph.D. Thesis, Universidade Federal do Paraná, Curitiba, Brasil.

Simpson, W. T. 1991. Dry kiln operator's manual. Madison-Wisconsin, Madison.

Susin, F. 2012. Avaliação de programas de secagem para madeiras de eucalipto elaborados com base em testes prévios a alta temperatura. M.S. Thesis, Universidade Federal de Santa Maria, Santa Maria, Brasil.

Terazawa, S. 1965. Methods for easy determination of kiln drying schedule of wood. Wood Industry 20 (5): 216-226. 
Zanuncio, A.J.V; Carvalho, A.G.; Silva, L.F.; Lima, J.T.; Trugilho, P.F.; Silva, J. R. M. 2015. Predicting moisture content from basic density and diameter during air drying of Eucalyptus and Corymbia logs. Maderas. Ciencia y Tecnología 17 (2): 335-344. 